\title{
Supporting the process of removing humic substances on activated carbon
}

\author{
Paulina Olesiak $^{\bowtie}$ and Longina Stępniak \\ Czestochowa University of Technology, Faculty of Environmental Engineering and Biotechnology, Institute for Environmental Engineering \\ Częstochowa, Poland
}

This study is focused on biosorption process used in water treatment. The process has a number of advantages and a lot of research has been done into its intensification by means of ultrasonic modification of solutions. The study carried out by the authors leads to the conclusion that sonication of organic solutions allows for extension of the time of operation of carbon beds. For the analysis of the results obtained during the sorption of humic substances (HS) from the solution dependencies $\mathrm{UV} / \mathrm{UV}_{0}$ or $\mathrm{DOC} / \mathrm{DOC}_{0}$ were used. In comparative studies the effectiveness of sorption and sonosorption (UV/ $U_{0}$ ) shows that the share of ultrasounds (US) is beneficial for extension of time deposit, both at a flow rate HS solution equal to $1 \mathrm{~m} / \mathrm{h}$ and $5 \mathrm{~m} / \mathrm{h}$. Analysis of the US impact sorption on HS sorption in a biological fluidized bed, both prepared from biopreparat and the activated sludge confirms the higher efficiency compared to sonobiosorption than biosorption. These results confirm the degree of reduction $\mathrm{UV}_{254} / \mathrm{UV}_{0}$ and $\mathrm{DOC} / \mathrm{DOC}_{0}$ for the same processes. EMS index also confirms the improvement of HSbiodegradation by sludge microorganisms.

Key words: water treatment, biosorption, biodegradation, ultrasounds

Received: 15 October, 2013; revised: 09 August, 2014; accepted: 25 August, 2014; available on-line: 04 November, 2014

\section{INTRODUCTION}

\section{Adsorption on activated carbon}

Modernization of contemporary technological systems of water treatment, driven by the necessity of removal of organic compounds from water, needs first and foremost inclusion of sorption on granulated activated carbon (AC). This process has been increasingly used in water treatment plants since it is the least problematic among the available methods. Adsorption on AC is a very convenient solution due to large surface areas typical of porous materials. The opportunities of recovery of $\mathrm{AC}$ are also very important from the economic standpoint as it elongates life of carbon beds and reduces its operating costs (Yu et al., 2005). Used an example of Dzieckowice Water Treatment Plant, the costs of carbon filters in the whole process of water treatment might reach $15 \%$, while carbon regeneration helps reduce them by nearly $50 \%$ (Wojciechowska, 1998). An additional advantage is that carbons can be used for sorption of both organic and inorganic contaminants during a single process. The rough porous surface of carbon provides a perfect base for colonization of AC molecules by microorganisms. AC is characterized by hydrophobic surface. The most important parameter of carbons is their porosity i.e. well-developed specific surface which reaches even up to $1000 \mathrm{~m}^{2} / \mathrm{g}$.

The three hypothetical models of HS sorption on AC were shown (Świderska \& Anielak, 2004).

An important factor that affects the method of HS sorption of the sorbent is $\mathrm{pH}$ of the solution. Therefore, way the particles of HS are adsorbed on AC might occur according to the following patterns:

$\mathrm{S}-\mathrm{OH}+\mathrm{H}^{+}=\mathrm{S}_{-} \mathrm{OH}_{2}^{+}$

with acid reaction

$\mathrm{S}-\mathrm{OH}+\mathrm{H}_{2} \mathrm{O}=\mathrm{S}-\mathrm{OH}+\mathrm{H}_{2} \mathrm{O}$

with neutral reaction

$\mathrm{S}-\mathrm{OH}+\mathrm{OH}^{-}=\mathrm{S}_{-} \mathrm{O}^{-}+\mathrm{H}_{2} \mathrm{O}$

with alkaline reaction

The first of them concerns the conditions of the acid environment where the exchange of ligand between protons in the $\mathrm{OH}_{2}{ }^{+}$group from the sorbent and carboxyl groups from humic substance occurs. The process of sorption usually occurs more effectively for acid reaction. This can be explained by the fact that AC has a positive surface charge and electrostatic interactions with the humic substance with negative charge are likely to occur. This can be presented by the following:

$\mathrm{S}-\mathrm{OH}+\mathrm{H}^{+}=\mathrm{S}-\mathrm{OH}_{2}^{+}$

$\mathrm{S}-\mathrm{OH}_{2}{ }^{+}+\mathrm{HS}_{-} \mathrm{COO}^{-}=\mathrm{S}_{-} \mathrm{OH}_{2}{ }^{+} \mathrm{OOC}-\mathrm{HS}$

$\mathrm{S}-\mathrm{OH}_{2}{ }^{+}$OOC-HS $=$S-OOC-HS $+\mathrm{H}_{2} \mathrm{O}$

If both sorbent and HS have negative charges, the binding might result from bridging through many multivalent cations such as $\mathrm{Ca}^{2+}, \mathrm{Mg}^{2+}$, or $\mathrm{Al}^{3+}$.

$\mathrm{S}-\mathrm{OH}+\mathrm{H}_{2} \mathrm{O}=\mathrm{S}-\mathrm{O}^{-}+\mathrm{H}_{3} \mathrm{O}^{+}$

$\mathrm{S}-\mathrm{O}^{-}+\mathrm{Ca}^{2+}+\mathrm{HS}^{-\mathrm{COO}^{-}}=\mathrm{S}-\mathrm{O}-\mathrm{Ca}-\mathrm{OOC}-\mathrm{HS}$

\section{Biosorption}

Two types of processes are observed when using BAF. Usually one of them is advantageous, but they might be in a state of equilibrium. The first phase of the process is dominated by the process of sorption and, after adsorption of a particular amount of contaminant, the second process occurs (biodegradation) (Sakoda et al., 1996). Prevalence of one process over the other (or

e-mail: paulina_olesiak@interia.eu

Abbreviations: $\overline{A C}$, activated carbon; DOC, dissolved organic carbon; HS, humic substances; US, ultrasounds; UV, ultraviolet 
their equilibrium) was described by the index proposed by Eberhardt, Madsen and Sontheimer $($ EMS $=s)$. It is expressed by the ratio of oxidability (measured by means of permanganate or chromate methods) to the value of solved oxygen

$s=\Delta \mathrm{ChZT} / \Delta \mathrm{O}_{2}$

Depending on $s$ index, different processes might be observed:

$s=1$ : equilibrium between sorption and biodegradation processes,

$s<1$ : prevalence of biodegradation,

$s>1$ : prevalence of sorption,

$s=0\left(\Delta \mathrm{ChZT}=0\right.$ and $\left.\Delta \mathrm{O}_{2}=0\right)$ : neither of the processes occurs; $\left(\Delta\right.$ ChZT $>0$ and $\Delta \mathrm{O}_{2}=0$ ): only sorption is observed (Perchuć

\& Grabińska-Loniewska, 1998).

In nature, microorganisms are present in water. Therefore, each bed used under industrial conditions, after particular operating time, is colonized by microbial consortia. The type and the rate of biomass growth depends on several conditions, such as access of oxygen and organic matter, $\mathrm{pH}$, type and content of contaminants or presence of toxic substances in water. AC provides a good base for colonization by bacteria because of their porous structure. It is build up on the external surface of the carbon, which is much rougher. The pore interiors are smooth, therefore microorganisms are unwilling to colonize them (Walker \& Weatherley, 1999; Wolborska et al., 2003; Papciak, 2004; Mołczan, 2006; Duan et al., 2007; Yapsakli \& Cecen, 2010).

A good source of microbial consortia is provided by activated sludge. It represents an advanced biocenosis which positively interacts during biochemical processes. Therefore, activated sludge is used as a substrate for investigations of the effectiveness of biosorption and biodegradation of contaminants.

An example of a scientific publication describing the use of activated sludge in biodegradation is a paper showing the degradation of fluoranthene with high efficiency, just by activated sludge microorganisms (Piekarska, 1994).

Decomposition of the organic compounds adsorbed on the surface of sorbent is based on heterotrophic bacteria present in water and soil. A study demonstrated that the use of preparations containing microorganisms and enzymes can be justified. This is confirmed by the studies on the use of DBC-PLUS preparation for biodegradation of petroleum derivative substances from oilcontaminated soils (Papciak \& Zamorska, 2004).

\section{Ultrasonic modification of biosorption process}

Process modification consists in application of combination methods that allow for more effective water treatment taking into consideration the environmental protection as well as the economic aspects. The most frequently used methods of modification in biotechnology include: oxidation, photolysis, sonication and the methods that combine these processes.

One of the relatively new technologies used in research studies is ultrasonic modification. A sono-sorption, which is the use of the energy of US field, is an example of modification of sorption. US can be used with respect to $\mathrm{AC}$, solutions or the whole systems of carbon with solution (which is easier in the case of the processes carried out in static conditions). US initiate changes in a system exposed to US field through elevating pressure and temperature. US might promote oxidation/re- duction in a solution, degradation of polymers and other chemical compounds, and have effect on reaction time (Stępniak, 2006; Stępniak et al., 2009). Generation of the waves leads to formation of cavitation bubbles with the temperature of $5000 \mathrm{~K}$ and pressure of 500 at. The bubbles are chiefly responsible for sonochemical reactions (Mason et al., 2003). Cavitation in water might cause two types of reaction to contaminants: chemical oxidation that uses highly reactive free radicals or decomposition of macromolecules affected by a high-impact wave. The cavitation process consists in compression of the bubbles and thermal dissociation of water particles according to the following reactions:

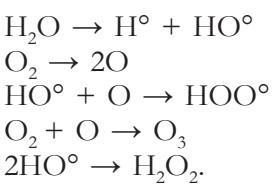

These reactions lead to formation of ozone, $\mathrm{H}_{2} \mathrm{O}_{2}$ and radicals: $\mathrm{H}^{\circ}, \mathrm{HO}^{\circ}, \mathrm{HOO}^{\circ}$ with high reactivity (Chemat et al., 2001). The idea behind sonication process in sorption is to obtain the compounds with lower molecular mass, which are easier adsorbed by micropores (increase in carbon sorption capacity), easier biodegraded, and better assimilated by microorganisms.

Different organic compounds have been extensively researched by the scientists who test the usefulness of exposure to US. Examples of such compounds is saccharin which is more bioabsorbable involving US (Bernardo et al., 2006). These researchers demonstrated that US have effect on improved sorption of saccharin. Increased sonication time causes a reduction in TOC concentration. Other studies measured the effect of US on operation of biological filters, who reported a positive effect of US with power of $10 \mathrm{~W}$ that caused an increase in bacterial count in the bed, which resulted in improved biodegradation of organic compounds in a bioreactor (Liu et al., 2005). Results of microbiological examination of water disinfection with US fields indicate a high degree of decontamination of microorganisms. However, sonication should be connected e.g. with ozone, UV radiation or chlorination (Mason et al., 2003)

Studies on the use of US field for bed regeneration showed that US promote desorption of the compounds. This phenomenon can be useful in the regeneration of the bed, which can not be subjected to heat and chemical processes, as it is in the polymeric adsorbents (Breitbach \& Bathen, 2001).

US are also used in such processes as water disinfection or as an agent that stimulates growth and biochemical transformations in microorganisms (Liu et al., 2005). The US (with power of $10 \mathrm{~W}$ ) might increase biological activity of Sacharomyces cerevisiae. The effect of sonication was maintained for $24 \mathrm{~h}$. Furthermore, US field has been successfully used in disintegration of bacteria cells coming from sewage sludge (Nickel \& Neis, 2007; Jiang et al., 2011). The former authors obtained satisfactory results of the effect of US on decomposition of a biological bed, which caused an increased yield of biofuel. Jiang and his co-authors used US for initial processing of sewage sludge. The results obtained by these authors led them to the conclusion that the degree of removal of the organic matter after the use of US increased from $11-19 \%$ to $25-57 \%$.

The aim of the present study was to evaluate the efficiency of US-ssistance biosorption of HS. 


\section{Combined methods}

There is a tendency among the researchers who investigate new methods used in the process of water treatment to employ several partial processes. This often leads to improved effectiveness especially through enhancement and initiation of other processes. The most popular example of using combined methods is oxidation.

US field used during the process of removal of organic compounds has attracted little scientific attention in the world. The results of studies were carried out with sono-oxidation and showed that degradation of HS, determined by the content of total organic carbon (TOC) was possible just after one hour (Chemat et al., 2001). The rate of removal of HS as TOC (Kim et al., 2007) was studied. These authors described the relationship between increased dose of $\mathrm{H}_{2} \mathrm{O}_{2}$ and TOC removal rate. A method of oxidation combined with sonication or ultraviolet radiation for removal of humic acids was also used (Mahvi et al., 2009). They demonstrated that photodegradation occurs at increased efficiency and at shorter time than the simultaneous ultrasonic degradation.

The reasearch in the removal of humic acids and concentrated natural organic substances was carried out (Raczyk-Stanisławiak et al., 2007).

Used carbon F-400, filtration rate was $10 \mathrm{~m} / \mathrm{h}$. Biofiltration was aided with ozonation. These activities allowed for removal of DOC by $24 \%$ during 30-minute contact of carbon with the solution, by $21 \%$ for 15 minutes and by $8 \%$ for 5 -minute contact time. $\mathrm{UV}_{254}$ was reduced by $60 \%$ with the same contact time. The increase in the time of contact between the bed and carbon up to 60 minutes improved the effectiveness to $65 \%$.

Analysis of HS sorption on biological filter using a power supply with an initial ozone showed improvement in process efficiency by $10 \%$. As mentioned above, the HS biodegradation by microorganisms has been assisted with the activated sludge (Kaleta, 2004).

\section{MATERIALS AND METHODS}

The study used 1-metre filtration columns with internal diameter of $0.026 \mathrm{~m}$, filled with carbon bed. The adsorbent was provided by AC ROW 08 Supra (Norit). The height of the carbon bed was $0.5 \mathrm{~m}$. The rate of solution flow through the column from the top to the bottom was constant $(1 \mathrm{~m} / \mathrm{h}$ or $5 \mathrm{~m} / \mathrm{h})$. Adsorbate was provided by a commercial preparation of humic acids (manufactured by Acros Organics, with content of humic acids of $50-60 \%$ ). For this purpose, the authors prepared a model solution of HS with concentration of 20 $\mathrm{mg} / \mathrm{dm}^{3}$ based on deionized water. The study evaluated the opportunities for increasing the process effectiveness through ultrasonic modification of HS solution. An ultrasonic disintegrator VCX 750 (Sonics) with the frequency of $20 \mathrm{kHz}$ was used. Solution sonication was carried out for 1 minute and amplitude of 100\% (114 $\mu \mathrm{m})$. The biological carbon filter design included microbial consortia of a commercial biopreparation (Enzybac, manufactured by Biozym) - containing lyophilized bacteria and enzymes designed for sewage treatment plants, or activated sludge - from Sewage Treatment Plants ZGK in Mstów). Carbon filters were created by flooding the AC by solution of biopreparation or sludge for a period of one month for the culture conditions, such as the daily portioning of organic matter in very small ration (HS) and aeration of the bed by mixing.
In order to evaluate the process effectiveness, the absorbance $\mathrm{UV}_{254}$ (Spectrofotometr Termo Electron Corporation Helios $\alpha$ SpectroLab) two times and dissolved organic carbon DOC (carbon analyzer multi N/C 2100 Analytikjena) three times, were measured in the eluate samples. Measurement of $\mathrm{UV}_{254}$ absorbance is regarded as a basic method used for evaluation of organic contaminants in water (Szumielewicz, 1993; Mołczan et al., 2006; Mołczan, 2007; Figiel, 2012). DOC represents a more accurate measure which directly indicates the content of dissolved organic carbon in HS. Therefore, our main focus was on measurement of this parameter. Appropriateness of the indices of organic contamination (UV, DOC) adopted in the study has been demonstrated by the previous study on the effect of US on humic acid solutions (Steppniak et al., 2009). This study has shown that reduction in these indices causes a reduction in $\mathrm{SUVA}_{254}\left(\mathrm{UV}_{254} / \mathrm{DOC}\right)$. Evaluation of $\mathrm{SUVA}_{254}$ index in the publication concerned solutions of $\mathrm{HS}^{254}$ subjected to sonication, without taking sorption into consideration. In the author's own research, the US field was used for HS solutions before introducing them to carbon filters. DOC levels were evaluated in the samples of eluate, filtered using syringe filters (membrane cellulose acetate, pore diameter: $0.45 \mu \mathrm{m}$ ). Further research will extend evaluation of humic acid levels in model solutions (made of commercial preparation of salts of humic acid) with a combined extraction and spectrophotometric method. HA-DOC and HA$\mathrm{UV}_{254}$, curves with specific correlations will be used to determine actual concentration of humic acid.

Changes in these indices were evaluated based on the initial values (absorbance $\mathrm{UV}_{0}$ and $\mathrm{DOC}_{0}$ ) and final values (absorbance UV and DOC) expressed as a value of $\mathrm{UV} / \mathrm{UV}_{0}$ and DOC/ $\mathrm{DOC}_{0}$. In the case of the columns with biological bed, the authors also determined the level of dissolved oxygen (PN-C-04545-08:1972P electrochemical method using Elmetron oxygen meter) in order to calculate the EMS index that allows for determination of the contribution of the processes that occurred in the column (sorption and biodegradation). To determine the value of EMS, the COD oxidisability or organic compounds in the solution discharged from the column was also necessary to examine. The permanganate (PN-EN ISO 8467:2001) was applied for this method. Equation $\mathrm{EMS}=s$ ratio has been described in part Introduction: Biosorption.

The final time of the column operation was represented by the time of obtaining $95 \%$ of initial concentration in HS solution determined based on absorbance $\mathrm{UV}_{254}$.

\section{RESULTS AND DISCUSSION}

HS solutions in various systems were characterized by UV range 0.405-0.465 and DOC range 5.26-7.27.

Analysis of the results obtained in the study concerning sorption of HS carried out on a carbon bed for two different flow rates $(V=1 \mathrm{~m} / \mathrm{h}$ and $\mathrm{V}=5 \mathrm{~m} / \mathrm{h}$, see Fig. 1) allowed for evaluation of HS removal in these processes. Comparison of the degree of HS removal from $\mathrm{UV} / \mathrm{UV}_{0}$ relationship in the first phase of the process suggests a higher effectiveness of the bed with lower flow rates. Furthermore, the final phase of sorption suggests improved results for higher rates: elongation of operating time by nearly 100\%. Sono-sorption, described with the same relationship, points to a comparable effectiveness of the process for the flow rates of $V=5 \mathrm{~m} / \mathrm{h}$. 


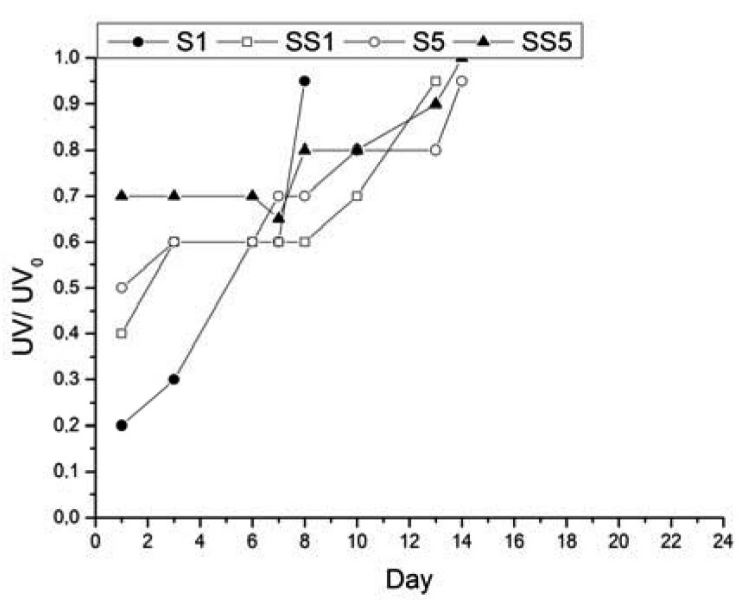

Figure 1. Degree reduction UV/ UV $\mathrm{V}_{0}$ in HS solution

S1-sorption $(\mathrm{V}=1 \mathrm{~m} / \mathrm{h})$; S5-sorption $(\mathrm{V}=5 \mathrm{~m} / \mathrm{h})$; SS1-sonosorption $(\mathrm{V}=1 \mathrm{~m} / \mathrm{h})$; SS5-sonosorption $(\mathrm{V}=5 \mathrm{~m} / \mathrm{h})$.

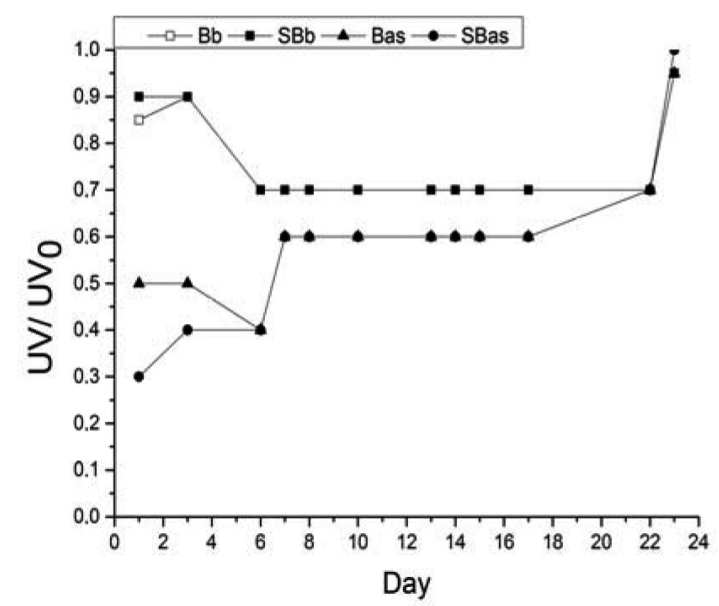

Figure 2. Degree reduction UV/ UV in HS solution $(\mathrm{V}=1 \mathrm{~m} / \mathrm{h})$ Bb-biosorption by biopreparat, SBb-sonobiosorption by biopreparat; Bas-biosorption by activated sludge; SBas-sonosorption by activated sludge.

With the rate of $1 \mathrm{~m} / \mathrm{h}$, sonication caused a considerable elongation of column operation life.

Comparative analysis of the initial phase showed higher effectiveness of sewage sludge compared to biopreparation and an advantageous effect of US (higher degree of HS reduction in the sonificated systems, see Fig. 2). Analysis of sorption and sono-sorption that used bacteria of biopreparation and sewage sludge based on the $\mathrm{UV} / \mathrm{UV}_{0}$ ratio suggests similar process effectiveness and similar column operation time in the final phase for both sources of bacteria (Fig. 2). No effect of sonication of HS solutions on process effectiveness was recorded in this phase. Comparison of $\mathrm{DOC} / \mathrm{DOC}_{0}$ for the beds with biopreparation and activated sludge showed similar relationships as in the case of $\mathrm{UV} / \mathrm{UV}_{0}$ (Fig. 3). The system, which HS reduction was the most effective in the first phase of the process, was an US-modified biosorption bed with bacteria of activated sludge, followed by the bed without ultrasonic modification and the biosorption bed of biopreparation (modified and basic). The final phase was characterized by different effects i.e. insignificant improvement in the biodegradation process using the bacteria of the activated sludge in the system

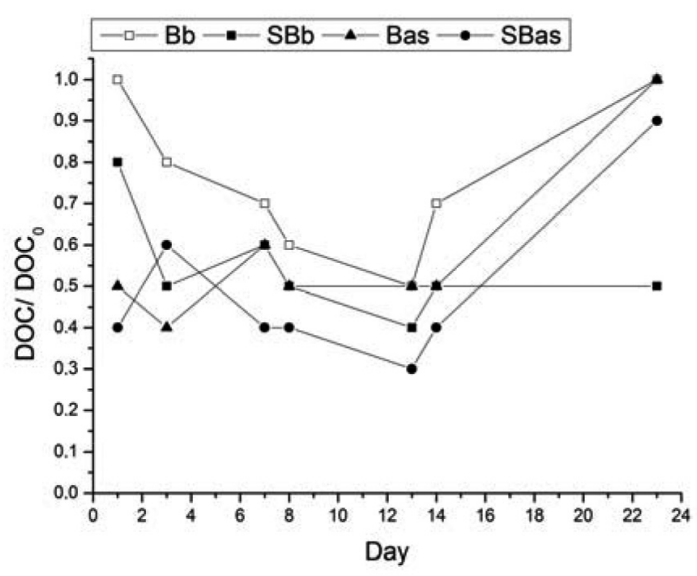

Figure 3. Degree reduction $D O C / D O C_{0}$ in HS solution $(V=1 \mathrm{~m} / \mathrm{h})$ Bb-biosorption by biopreparat, $\mathrm{SBb}$-sonobiosorption by biopreparat; Bas-biosorption by activated sludge; SBas-sonosorption by activated sludge.

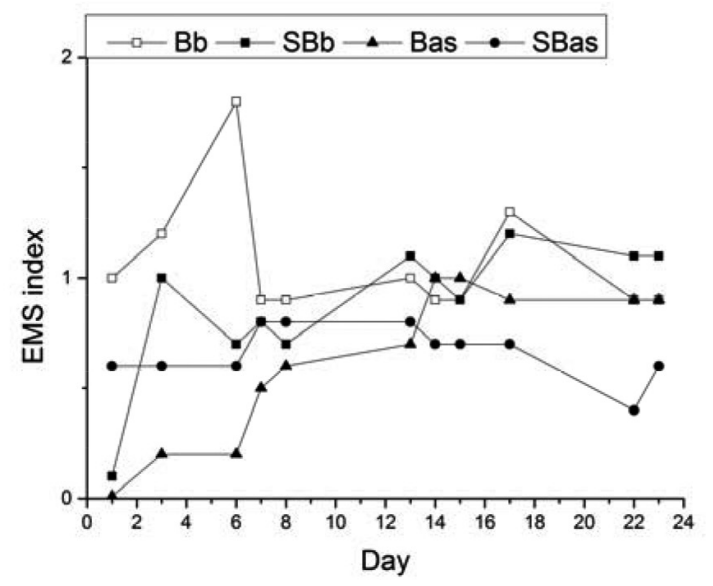

Figure 4. EMS index $(\mathrm{V}=1 \mathrm{~m} / \mathrm{h})$

Bb-biosorption by biopreparat; SBb-sonobiosorption by biopreparat; Bas-biosorption by activated sludge; SBas-sonosorption by activated sludge.

modified with US field with respect to the basic system; high and maintained degree of HS removal in the biological system with biopreparation modified with US field.

Evaluation of the EMS index points to differences in biological activity of the bacteria that colonize the biological beds studied (Fig. 4). The bed obtained using biopreparation was characterized by the advantage of sorption in initial and final phases of the process. Biodegradation was dominant in the middle phase. It was observed that the US field favourably affected biodegradation in the 1 st phase while the 2 nd phase exhibited advantage of sorption over biodegradation. Better results of HS biodegradation were observed in the filter obtained using sewage sludge bacteria. Biodegradation showed advantage from the beginning of bed operation and the equilibrium between sorption and biodegradation processes (EMS index at the level of 1) was maintained as the bed was depleted.

The process of contaminant sorption by means of AC has been the focus of scientific interest over many years. However, the problems of removal of HS from water are being investigated by few researchers. The process is 
difficult and complex due to its design and the nature of HS (macromolecules, unknown structure, potential for formation of coloids and mutagenic compounds). The present investigations were carried out towards the use of US field for intensification of the process of adsorption of HS from water. In order to evaluate the effect of US field on sorption of HS, the authors examined the effect of sonication on biological beds. Among Polish scientists in the field of removing organic compounds in the sorption process on AC, one should emphasize several studies. The use of ROW 08 Supra carbon was analysed and it was found that the parameters studied were decreased on average by: $39 \%$ for oxidability, $47 \%$ for $\mathrm{UV}_{254}, 75 \%$ for turbidity and $63 \%$ for colour (Kiedryńska, 2004). Bed height was $2 \mathrm{~m}$, external diameter of the column was $200 \mathrm{~mm}$ and the time of contact of water with the bed was 30 minutes. The bed was provided by a biological filter, which had been build up for about 1 year before the experiment. The study found the highest rate of removal of organic matter from AC at the flow rate of $1 \mathrm{~m} / \mathrm{h}$ based on absorbance UV and DOC using bacteria (Figs. 2, 3). During the study carried out in Gruszczyna Water Treatment Plant, biological bed activity and changes in the physical and chemical parameters of water after treatment (including TOC, oxidability, $\mathrm{UV}_{254}$ ) (Pruss et al., 2009) were examined. After analysis of the samples, these researchers reported a decline in oxidability, TOC and $\mathrm{UV}_{254}$, by ca. $30 \%, 14 \%$ and $25 \%$, respectively. The study was carried out in four parallel biological filters $(0.15 \mathrm{~m}$ in diameter, $3 \mathrm{~m}$ in height and filtration rate of $5-10 \mathrm{~m} / \mathrm{h}$ ) with water supply from Warta river, the researchers evaluated e.g. $\mathrm{UV}_{254}$, TOC and COD (Sozański et al., 1993).

The decline in TOC ranged from 8 to $15 \%$, depending on bed operating time. For $\mathrm{UV}_{254}$ this effectiveness ranged from $28 \%$ to $78 \%$. The above values of sorption effectiveness were observed in the beginning of bed operation. During the pilot study carried out in Kalinko Water Treatment Plant, the researchers developed recommendations for the process after changing the rapid graveller filters into carbon filters (Wolborska et al., 2003). The bed height was $1.1 \mathrm{~m}$, the internal diameter was $1 \mathrm{~m}$ and the flow rate for the water supplied to the filter was $2 \mathrm{~m} / \mathrm{h}$. Bed filling was provided by granulated carbon TL830. Analysis of bed performance was based on the following parameters: $\mathrm{pH}$, turbidity, colour, smell, oxidability, TOC, DOC, $\mathrm{UV}_{254}$. A reduction in water oxidability ranged from $33 \%$ to $69 \%$, DOC decreased by ca. $30 \%$ and $\mathrm{UV}_{254}$ by about $60 \%$. Bed biological activity was also determined by means of EMS test. Biosorption process showed a considerable advantage after filtration of about $6000 \mathrm{~m}^{3}$. The results of the experiments carried out in order to evaluate biological activity of beds are illustrated in Fig. 4. The diagram shows that the process of biosorption was the most advantageous during the processes. Research conducted in the WTP Goczałkowice that work with time deposits (microbial growth), the biological degradation of the contaminants, which observed by loss of oxygen dissolved in water subjected to filtration. In the summer periods (temperature rise and growing number of micro-organisms) the loss of oxygen is higher (Szostak, 2013). The bed that had the highest biological activity was provided by the filter obtained based on activated sludge bacteria. A different effect of US on the bed studied was also found, i.e. activity of biopreparation decreased with time of bed operation while the activity of activated sludge was rising.
In studies of sorption aided with other factors were carried out, who analysed sonosorption of HS on granulated AC (Kusiak et al., 2011). These papers demonstrated that sonication of the solution of HS leads to enhanced efficiency of the process.

\section{CONCLUSIONS}

Analysis of the results obtained in the present study leads to the following conclusions:

Higher degree of HS removal described by a change in absorbance $\mathrm{UV}_{254}$ was reported at lower rates of $\mathrm{V}=1$ $\mathrm{m} / \mathrm{h}$. Elongation of bed operation time in the system with ultrasonic modification of HS solution was also observed.

Operation of biological beds obtained based on biopreparation and activated sludge suggests improved effectiveness of the process of removal of HS and elongation of operating time of columns compared to the system of sorption.

Comparison of HS biosorption with the use of bacteria of biopreparation and activated sludge points to improved effectiveness of the process after application of US field in order to modify HS in the solution.

EMS index determined for biological beds points to the advantage of biodegradation over sorption and varied impact of US on biological activity of bacteria i.e. stimulation in the 1 st phase with respect to biopreparation and in the 2 nd phase with respect to activated sludge.

\section{Acknowledgements}

The study was financed from funds allocated to the grant for young scientists BS/MN-401-321/11.

Paulina Olesiak is a DoktoRIS project's scholar (DoktoRIS is a scholarship project for development of innovation in Silesia region).

\section{REFERENCES}

Bernardo EC, Fukuta T, Fujita T, Ona EP, Kojima Y, Matsuda H (2006) Enhancement of saccharin removal from aqueous solution by activated carbon adsorption with ultrasound treatment. Ultrasonics Sonochemistry 13: 13-18.

Breitbach M, Bathen D (2001) Influence of ultrasound on adsorption processes. Ultrasonics Sonochemistry 8: 277--283.

Chemat F, Teunissen PGM, Chemat S, Bartels PV (2001) Sono-oxidation treatment of humic substances in drinking water. Ultrasonics Sonochemistry 8: 247-250.

Duan H, Yan R, Koe LChCh, Wang X (2007) Combined effect of adsorption and biodegradation of biological activated carbon on $\mathrm{H}_{2} \mathrm{~S}$ biotrickling filtration. Chemosphere 66: 1684-1691.

Figiel D (2012) Characteristics of the available methods of measuring the content of organic compounds in water. Technologia Wody 3: $20-22$.

Jiang J, Zhao Q, Wei L, Wang K, Lee D-J (2011) Degradation and characteristic changes of organic matter in sewage sludge using microbial fuel cell with ultrasound pretreatment. Bioresource Technology 102: 272-277.

Kaleta J (2004) Humus substances in water medium. Zassyty Naukowe Politechniki Rzeszowskiej 218: 39-53 (in Polish).

Kiedryńska L (2004) Water treatment involving granular active carbon filters: problem of bacterial colonization. Ochrona Środowiska 26: 39_ 42 (in Polish).

Kim I, Hong S, Hwang I, Kwon D, Kwon J, Huang CP (2007) TOC and THMFP reduction by ultrasonic irradation in wastewater effluent. Desalination 202: 9-15.

Kusiak M, Okoniewska E, Stępniak L, Stańczyk-Mazanek E (2011) The effect of ultrasound of the effectiveness of organic compounds adsorption from water. Pol J Environ Studies 4A: 195-200.

Liu H, He Y, Quan X, Yan Y, Kong X, Lia A (2005) Enhancement of organic pollutant biodegradation by ultrasound irradation in a biological activated carbon membrane reactor. Process Biochem 40: 3002-3007. 
Mahvi AH, Maleki A, Rezaee R, Safari M (2009) Reduction of humic substances in water by application of ultrasound waves and ultraviolet irradiation. Iran J Environ Health Sci Eng 6: 233-240.

Mason TJ, Joyce E, Phull SS, Lorimer JP (2003) Potential uses of ultrasound in the biological decontamination of water. Ultrasonics Sonochemistry 10: 319-323.

Mołczan M (2006) Principles of mathematical modeling of the adsorption-biodegradation process in granular active carbon beds. Ochrona Środowiska 28: 9-14 (in Polish).

Mołczan M, Szlachta M, Karpińska A, Biłyk A (2006) Water quality assessment in terms of specific UV absorbance. Ochrona Środowiska 28: 11-16 (in Polish).

Mołczan M (2007) Effect of the anion exchange process on the change in the quality of organic water pollutants characterized by the specific UV absorbance (SUVA) and specific color absorbance (SCOA) values. Ochrona Środowiska 29: 13-19 (in Polish).

Nickel K, Neis U (2007) Ultrasonic desintegration of biosolids for improved biodegradation. Ultrasonic Sonochemistry 14: 450-455.

Papciak D (2004) The biosorption beds in technology of water purification. Zeszyty Naukowe Politechniki Rzeszowskiej 218: 85-94 (in Polish).

Papciak D, Zamorska J (2004) The possibility of using biopreparat DBC-PLUS in assist of crude oil compounds biodegradation process. Zesayty Naukowe Politechniki Rzeszonskiej 218: 95-107 (in Polish).

Perchuć M, Grabińska-Łoniewska A (1998) Technology research the effect of the type of coal used in the BAF to remove humic acids from drinking water. Materials of conference ,Wegiel aktywny $w$ ochronie środowiska”, pp 144-153. Published by Czestochowa University of Technology (in Polish).

Piekarska K (1994) Biosorption of fluoranthene by activated sludge. Ochrona Środowiska 2: 7-10 (in Polish).

Pruss A, Maciołek A, Lasocka-Gomula I (2009) Effect of the biological activity of carbon filter beds on organic matter removal from water. Ochrona Środowiska 31: 31-34 (in Polish).

Raczyk-Stanisławiak U, Ciemniecka E, Świetlik J, Nawrocki J (2007) Removal of the precursors of biodegradable organic substances via biofiltration. Ochrona Środowiska 3: 59-64 (in Polish).
Sakoda A, Wang J, Suzuki M (1996) Microbial activity in biological activated carbon bed by pulse responses. Water Science Technology 34: 213-222.

Sozański MM, Sozańska Z, Sobczyński T (1993) Removal of the micropollutants on biologically active carbon filter beds at increased water salinity level. Ochrona Środowiska 3: 57-60 (in Polish).

Stepniak L (2006) The use of the ultrasonic field for aiding the coagulation process in water treatment. Monograph No. 112, Published by Czestochowa University of Technology (in Polish).

Stępniak L, Kępa U, Stańczyk-Mazanek E (2009) Influence of a high-intensity field on the removal of natural organic compounds from water. Desalination and Water Treatment 5: 29-33.

Szostak A (2013) Carbon filters at the Department of Water Treatment Goczałkowice - ten years of experience, Report presented at the conference "Wegiel aktywny w ochronie środowiska i przemyśle" (unpublished materials), Białowieża (in Polish).

Szumielewicz J (1993) Evaluation and selection of activated carbon by ultraviolet absorbance measurement. Ochrona Środowiska 3: 65-68 (in Polish).

Świderska R, Anielak AM (2004) The significance of electrocinetic potential in the adsorption process of humic substances. Rocznik Ochrony Środowiska 6: 31-49.

Wojciechowska K (1998) Research shares carbon filters in water treatment costs. Materials of conference: "Wegiel aktywny w ochronie środowiska”, pp 83-92. Częstochowa (in Polish).

Wolborska A, Zarzycki R, Cyran J, Grabowska H, Wybór M (2003) Ecaluating in biological activity of carbon filters in surface water treatment: a case study. Ochrona Środowiska 25: 27-32 (in Polish).

Yapsakli K, Cecen F (2010) Effect of type of granular activated carbon on DOC biodegradation in biological activated carbon filters. Process Biochemistry 45: 355-362.

Yu G, Lu S, Chen H, Zhu Z (2005) Diesel fuel desulfurization with hydrogen peroxide promoted by formic acid and catalyzed by activated carbon. Carbon 43: 2285-2294. 